\title{
Robert Jervis: Illuminating the Dilemmas of International Politics
}

\author{
Jack Snyder, Columbia University
}

\begin{abstract}
$A^{\mathrm{PSA}}$
PSA President Robert Jervis stands out among contemporary scholars of international politics for his highly original, multifaceted contributions to understanding the dilemmas of conflict and cooperation, especially in the nuclear age. He has shown in a compelling fashion how the efforts of political leaders and strategists to escape from the insecurities of international competition often only compound these dangers. While remaining alert to the role that greedy aggressors play in fomenting conflict among states, Jervis has stressed the more surprising and tragic sources of conflict that can embroil even states that mainly seek security from each other. He has pointed out the misperceptions, unintended consequences, and perverse situational dilemmas that trip up statesmen in the hope that leaders can better understand and guard against these pitfalls.

While studying problems of international security, Jervis has made contributions to basic social science in a broad range of fields. He originated the distinction between signals and indices in strategic bargaining, phenomena now commonly referred to as "cheap talk" and "costly signals." He pioneered the sophisticated application and elaboration of the laboratory findings of cognitive psychology to problems of realworld political decision making. He has played a central role in theoretical dialogues between historians and political scientists on the nature of the international system. Most recently, he has explored feedback effects in complex systems of all kinds, ranging from supertanker safety systems to the balance of power.

Jervis has been driven not by an $a$ priori commitment to any particular theoretical "ism," but rather by a desire to solve the puzzles posed by the substantive problem of international cooperation in the face of the
\end{abstract}

danger of war, especially nuclear war. Thus, his work constitutes a conundrum for the many international relations specialists who like to pigeonhole thinkers into categories such as realists, liberals, rationalists, constructivists, or positivists. Jervis is a realist in that he argues that anarchical circumstances pose distinctive problems, yet he has diverged from many realists by arguing that actors' perceptions and misperceptions of these circumstances and of the intentions of their adversaries crucially shape their choices about how to compete or cooperate. Jervis is a rationalist who has made seminal contributions to the conceptual underpinnings of game theory and bargaining, yet the bulk of his work shows how political actors' rationality is confounded by the cognitive shortcuts they take and by their inability to predict the consequences of their actions in complex systems. Methodologically, Jervis is a positivist who has laid out a scrupulously rigorous methodology for assessing ideas' influence on behavior, yet he has also explored the limits of conventional positivism in understanding nuclear symbolic politics and complex feedback effects.

It would be wrong, however, to label Jervis's work eclectic. His writings show him to have a consistent view of international politics as structured by complex systems of interaction, by the often myopic striving of actors to perceive the nature of the system they are operating in, and by wary actors' use or misuse of guile to deal with the problems of insecurity, opportunism, and uncertainty that are inherent in the workings of the system.

Jervis has been intellectually open to developments in a very wide range of disciplines, approaches, and

\section{APSA President-Elect (2000)}

Robert

Jevis

Adlai $\mathrm{E}$.

Stevenson

Professor of

Internationa

Politics

Columbia

University

B.A. Oberlin College, 1962

Ph.D. University of California, Berkeley,

1968 methodologies. At the same time, he has consistently applied rigorous criteria for social science argumentation: clarity of logic, faithfulness to empirical evidence, and sufficient theoretical complexity to permit scholars to come to grips with a complex reality. His open, yet demanding, intellectual style has made him an outstanding mentor for young scholars of various theoretical persuasions. For example, his most recently tenured students include contributors to realist theory such as Thomas Christensen and Randall Schweller, as well as Jonathan Mercer, who is well known for arguing that behavior in anarchy is a socialpsychological construction. Openness and rigor have also served Jervis well as the coeditor of the influential Cornell Studies in Security Affairs, which has been a leading force shaping that field's research agenda for the past two decades.

Jervis's body of thought can be categorized in terms of five interrelated themes: communication in strategic bargaining, perception and misperception in international politics, cooperation in anarchy, the nuclear revolution, and complex system effects and unintended consequences. 


\section{Communication in Strategic Bargaining}

Jervis has been a central contributor to research on communication in strategic bargaining, bridging from Thomas Schelling's seminal studies of the credibility of threats in the 1960s to contemporary game-theoretic examinations of bargaining under conditions of imperfect information. In The Logic of Images in International Relations (1970), Jervis adapted the dramaturgical insights of Erving Goffman's The Presentation of Self in Everyday Life to Schelling's concern with strategic bargaining. Jervis introduced the distinction between what he called "on the cheap" signals of an actor's intentions and indices of the actor's expected behavior, which are too costly or too integral to the actor's fundamental make-up to fake. Applying these ideas to problems of deterrence and bargaining in the nuclear era, he examined precisely the kind of subtleties in the use of signaling and the manipulation of indices that have become staples of the burgeoning literature on bargaining in conditions of imperfect information, such as the dynamics of reputation and commitment in the face of incentives for opportunism and deception. These themes provided the conceptual grounding for much of Jervis's later work on the role of perception in bargaining, on nuclear deterrence, and on conflict spirals and the security dilemma-all of which hinge on such problems as the misreading of an adversary's intentions or the difficulty of credibly committing not to attack an adversary.

Jervis has continued to write on questions of game theory, signaling, and bargaining (1988; forthcoming). Typically, his work has stressed that most variables driving behavior in games, such as the preferences of the actors and their mode of perceiving each other, are precisely the elements that most game theory simply takes as givens. His work in this area shows the importance of embedding formal game theory in a broad conceptual context, drawing on psychology and other sources of theoretical inspiration.

\section{Perception and Misperception in International Politics}

Since the appearance of his seminal article "Hypotheses on Misperception" (1968), Jervis has been the premier authority on perception in international relations. His comprehensive study Perception and Misperception in International Politics

(1976), creatively assessed the applicability of a wide range of psychological propositions to the study of deterrence failures, conflict spirals, intelligence failures, strategic assessments, and the full panoply of diplomatic judgments and misjudgments. The central message of the book is that perception is profoundly theorydriven, that decisionmakers tend to see what they expect to see, and that these expectations are often driven by stereotyped lessons of history, analogies, or routine scripts that provide shortcuts for making assessments under uncertainty. Unlike a number of more recent writers, Jervis did not see the causal role of "ideas" as supplanting that of external strategic circumstances. Rather he described a two-step process in which the impact of external reality on decisions is mediated by actors' perceptions and misperceptions of it. Also unlike some recent writers on "ideas," Jervis did more than merely describe the consequences of foreign-policy ideas that happened to prevail at a given time. Rather, he identified the processes through which actors typically acquire their beliefs and perceptions. Instead of stressing what is unique to a particular identity or culture, he examined the universal aspects of common perceptual biases, such as the cognitive shortcuts that lead actors to overestimate the extent to which their opponents intend the harmful consequences of their actions and underestimate the extent to which adversaries' actions are a reaction to an actor's own initiatives.

Many of the cognitive biases that Jervis explored exacerbate conflict between actors who would get along better if they understood the nature of the misperceptions complicating their rivalry. However, he pointed out that perceptual biases can cut both ways, and that real conflicts of interest often coexist with perceptual dilemmas. Thus, unlike some less subtle theorists of the role perceptual bias plays in international conflict, he did not conclude that the unilateral adoption of benign, conciliatory policies is a simple solution to most of these pitfalls. Rather, he counseled an awareness of the likely sources of misperceptions and constant self-monitoring.

While Jervis's work on perception has spurred the production of a number of important studies of cognitive biases in international affairs, its impact extends far beyond devotees of the cognitive approach. For scholars of diverse theoretical orientations, Jervis's writings have served as a constant reminder of how the problems of perception complicate any analysis of strategy and decision making. This is exactly the kind of cautionary mentality that Jervis hoped to inculcate.

\section{Cooperation in Anarchy}

Jervis's most-cited article, "Cooperation under the Security Dilemma" (1978), draws on Rousseau's parable of the stag hunt and the Prisoners' Dilemma game to show how status quo states can wind up arms-racing and fighting due to the fears engendered by the situation of anarchy. Jervis defines a security dilemma as a situation in which any state's efforts to increase its security necessarily decreases the security of others. In this situation, one side's efforts to reduce its insecurity through an arms build-up or through the conquest of strategic territory will inevitably trigger similar behavior by other security-conscious actors.

Many realists have written as if any anarchical situation creates this kind of dilemma. Jervis showed, however, that this is true only when the side that takes the offensive has the advantage. If defense is easier or cheaper than offense, as it often is in international politics and in military strategy, then the security dilemma is relaxed or even eliminated, because both sides can increase their security simultaneously by adopting nonthreatening measures of self- 
defense. This works best when offensive weapons and strategies are easily distinguishable from defensive ones. A nuclear-armed stalemate facilitates the defense of the status quo and thus eases the security dilemma, Jervis argued, because nuclear threats are issued more credibly by the side that is defending encroachments on its core interests.

In his typical two-step analysis, Jervis argued that it is not just the situation of anarchy, offensive technology, or barrier-free geography that heightens vulnerability to attack and thus intensifies the security dilemma. Strategists and political leaders have often misestimated the ease of attacking or defending. What really counts is their perception of the balance between offensive and defensive incentives, as well as their perception of the likelihood that the other "stag hunters" will defect from cooperation. According to Jervis, both strategic circumstances and the whole array of perceptual biases he discussed in his earlier work shape behavior under the security dilemma.

This seminal article spawned an immense literature on the security dilemma, testing its propositions against the historical record, debating ways to measure the causal variables in the theory, studying the origins of offensive and defensive strategies, applying the theory to grand strategy as well as military policy, and using the theory to devise more stable strategic postures. To take just one specific example, formal game theorist Robert Powell settled a major debate about the "relative gains problem" in international relations theory by showing that fears of asymmetrical gains from cooperation are logically a function of the degree of offensive advantage.

The concept of the security dilemma has also demonstrated its contemporary practical relevance. Although it is difficult to show that the U.S. political science literature directly affected European and Soviet thinking about "non-offensive defense" during the 1980s, it is nonetheless noteworthy that Mikhail Gorbachev's Jervisian "new thinking" about Soviet defense policy was a key component in the peaceful termination of the Cold War. In the 1990 s, security studies scholars, including Jervis (1999b), applied the concepts of the security dilemma to understanding the problems of ethnic and civil wars in anarchical failed states.

\section{The Nuclear Revolution}

In the early 1960 s, Thomas Schelling demonstrated brilliantly that when both sides had nuclear weapons that could survive a first strike, it was meaningless to analyze nuclear strategy and weapons balances as if nuclear weapons were conventional war-fighting tools. Rather, he showed, they are most properly assessed as weapons of terror. In a nuclear standoff, bargaining advantages go not to the side with more nuclear warheads (since capability is equal and absolute), but to the side with the stronger resolve to stand firm in the face of the shared risk that the conflict will spin out of control. Jervis, whose first book had drawn on a number of Schelling's insights, was frustrated to see that U.S. nuclear weapons policy was straying from Schelling's principles. He feared that the U.S. government was developing first-strike weapons that would intensify the nuclear security dilemma in the misguided assumption that deterrence required nuclear war-fighting capabilities.

To rebut these nuclear war-fighting doctrines, Jervis again invoked Schelling's first principles. In The Illogic of American Nuclear Strategy (1984), he showed how the halfway strategy of limited nuclear warfighting was riddled with internal logical contradictions, making no sense either from Schelling's perspective or from a consistent warfighting view. Jervis pushed this point even harder in The Meaning of the Nuclear Revolution (1989), laying out the reasons why nuclear warfighting is a delusion and how the stable balance of terror relaxes the security dilemma. While recognizably building on Schelling's logic, Jervis added important new insights by drawing on new ideas from cognitive psychology. For example, psychologists have found that most people are risk-averse when faced with the chance to grab gains, but are more risk-acceptant when seeking to forestall losses. Thus, Jervis reasoned that the side defending the status quo, and in particular the side defending its vital interests, should be more willing to run the shared risk of mutual annihilation. If so, the nuclear stalemate ought to make threats to change the status quo less credible and, consequently, should ease the security dilemma. With this analysis, Jervis shored up a weak point in Schelling's original arguments about strategic stability. Schelling had less convincingly based his arguments for the advantages of deterrent threats over compellent (change-inducing) threats on the greater tactical feasibility of irrevocably committing oneself to defend than to attack. Alexander George and other critics had pointed out that such tactical advantages of the defender could be overcome by controlled pressure or "salami tactics."

Jervis's work on the nuclear revolution stands as the definitive statement of this variety of strategic theory. In 1990, The Meaning of the Nuclear Revolution won the coveted Grawemeyer Award for Ideas Improving World Order.

\section{Complex System Effects and Unintended Consequences}

Beginning in late 1979 , Jervis turned his attention to a thorough study of feedback effects in complex systems. He first examined how feedback affected the balance of power systems (1979b). Brilliant diplomatists like Bismarck were exceptionally good at thinking through the multifarious rebound and ripple effects of their policies, but most mere mortal diplomatists in multipolar settings were commonly confounded by the unintended consequences produced by negative or positive feedback from their efforts. Jervis has since studied erroneous beliefs about positive feedback processes in international affairs, especially the flawed logic informing the Cold War domino theory (1991b), and how feedback affects such diverse processes as seat belt safety, 
birth control, and school desegregation. In complex, interconnected systems, causality rarely runs in a linear fashion. Jervis showed how the side effects and feedback effects of an action may cancel out or overwhelm the intended effect, as when adding safety devices lulls the operator into recklessness.

System Effects: Complexity in Political and Social Life (1997), winner of the best book award of APSA's political psychology section and of several other prizes, analyzes various kinds of unintended consequences of action in complex systems. Characteristically, Jervis offered subtle and indirect solutions for managing the problems of unforeseeable consequences. He suggests "doing things in twos," for example, balancing a threat with a concession to keep the system of relations as a whole in equilibrium. More generally, he advises actors to be prepared to profit from the reaction against the unsubtle policies of adversaries who do not understand feedback effects. As in his earlier work, Jervis's underlying message in System Effects is that the world is more complicated than most actors think, and that they need to keep open minds while assessing responses to their strategies.

In addition to these five central themes, Jervis has also written influential articles on security regimes and the Concert of Europe (1982, $1985 \mathrm{~b}$ ), the impact of the Korean War on the Cold War (1980), statistical and case study methods (1967, 1989), the transformation of world politics after the end of the Cold War (1991-92, 1993), and intelligence failures (1986b, 1986c, 198687). In all of these efforts, he has demonstrated his ability to see the world in its multifaceted complexity and to organize varied elements into an integrated framework for understanding behavior. The quintessence of the Jervis style is perhaps "How Decision-Makers Learn from History," the sixth chapter of Perception and Misperception. This essay shows his keen deductive logic, his rigor in assessing possible sources of spuriousness in qualitative causal inference, and his apt use of historical examples. Although Jervis's histori- cal examples are rarely longer than a paragraph or so, they are based on voluminous reading. His standing as an accurate, insightful judge of historical evidence is very high among historians.

Jervis is the Adlai E. Stevenson Professor of International Politics at Columbia University. He received his B.A. from Oberlin College in 1962 and his Ph.D. from the University of California, Berkeley in 1968. He has taught at Harvard, Yale, Hebrew University, and UCLA. A fellow of the American Association for the Advancement of Sciences and of the American Academy of Arts and Sciences, he is also a long-time member of APSA and served as the Association's vice president in 198889. His honors include the Nevitt Sanford Award for Distinguished Professional Contribution to Political Psychology, the Lionel Trilling Award for the best book by a Columbia faculty member (1998), and the Career Achievement Award, Security Studies Section, International Studies Association (1996).

\section{Selected Publications}

"The Costs of the Scientific Study of Politics: An Examination of the Stanford Content Analysis Studies." 1967. International Studies Quarterly 11(December).

"Hypotheses on Misperception." 1968. World Politics 20(April).

The Logic of Images in International Relations. 1970. Princeton University Press.

Perception and Misperception in International Politics. 1976. Princeton University Press.

"Cooperation Under the Security Dilemma." 1978. World Politics 30(January).

"Deterrence Theory Revisited." 1979a. World Politics 31(January).

"Systems Theories and Diplomatic History." 1979b. In Diplomatic History: New Approaches, ed. Paul Lauren. Free Press.

"Why Nuclear Superiority Doesn't Matter." 1979-80. Political Science Quarterly 94(Winter).

"The Impact of the Korean War on the Cold War." 1980. Journal of Conflict Resolution 34(December).

"Security Regimes." 1982. International Organization 36(Spring).

The Illogic of American Nuclear Strategy. 1984. Cornell University Press.

Psychology and Deterrence. 1985a. Coauthored with Richard Ned Lebow and Janice Stein. Johns Hopkins University Press.

"From Balance to Concert: A Study in International Security Cooperation." 1985b. World Politics 38(October).

"What's Wrong with the Intelligence Process?" 1986a. International Joumal of Intelligence and Counterintelligence 1(Spring).

"More than the Facts Will Bear." 1986b. International Journal of Intelligence and Counterintelligence 1(Spring).

"Representativeness in Foreign Policy Judgments." 1986c. Political Psychology 7(September).

"Intelligence and Foreign Policy: A Review Essay." 1986-7. International Security 11(Winter).

"Morality and Nuclear Strategy." 1987. In International Ethics in the Nuclear Age, ed. Robert Myers. University Press of America.

"Realism, Game Theory, and Cooperation." 1988. World Politics 40(April).

The Meaning of the Nuclear Revolution. 1989a. Cornell University Press.

"Rational Deterrence: Theory and Evidence." 1989b. World Politics 41(January).
The Logic of Images in International Relations. 2nd ed. 1989b. Columbia University Press.

"Domino Beliefs and Strategic Behavior." 1991. In Dominoes and Bandwagons: Strategic Beliefs and Superpower Competition in the Eurasian Rimland, ed. Robert Jervis and Jack Snyder. Oxford University Press.

"The Future of World Politics: Will It Resemble the Past?" 1991-92. International Security 16(Winter).

"International Primacy: Is the Game Worth the Candle?" 1993. International Security 17(Spring).

System Effects: Complexity in Political and Social Life. 1997. Princeton: Princeton University Press.

"Realism in the Study of World Politics." 1998. International Onganization 52(Autumn).

"Realism, Neoliberalism, and Cooperation." 1999a. International Security 24(Summer).

"Civil War and the Security Dilemma." 1999b. Coauthored with Jack Snyder. In Civil Wars, Insecurity, and Intervention, ed. Barbara Walter and Jack Snyder. Columbia University Press.

"Signaling and Perception." Forthcoming. In Political Psychology, ed. Kristen Monroe. 